\title{
As gentis patrícias: identidades e imagens femininas na primeira metade do século XX (1920/1940)
}

\section{The gentle patricians: feminine identities and images in the first half of the twentieth century (1920/1940)}

\author{
Jane Soares de Almeida ${ }^{2}$
}

\begin{abstract}
RESUMO
$\mathrm{O}$ artigo realiza uma releitura de algumas obras publicadas na primeira metade do século XX, dedicadas e dirigidas principalmente às jovens brasileiras, numa intencionalidade explícita de orientar suas atitudes e normas de conduta numa sociedade que se desejava progressista e esclarecida. Nestas são ressaltadas as várias qualidades femininas necessárias para o cuidado com o lar e a função materna, a educação necessária para cumprir com esse objetivo, assim como alguns posicionamentos quanto à sua inserção no espaço público. Mesclam-se conselhos, orientações, advertências, tudo composto para se moldar uma imagética que definia a identidade feminina voltada à domesticidade e por decorrência ao papel subalterno que era desejado para as mulheres na hierarquia social do período. O agrupamento dessas obras se deu pelo critério cronológico dado serem esparsas e de difícil acesso.
\end{abstract}

Palavras-chave: educação feminina; revistas; imagem; gênero; identidade.

${ }^{1}$ Artigo baseado em Conferência Proferida no 14. ${ }^{\circ}$ Encontro de Pesquisadores rio-grandenses de História da Educação, Universidade Federal de Pelotas, Rio Grande do Sul, Brasil, em 29 de outubro de 2008. A pesquisa realizada conta com financiamento do CNPq (Conselho Nacional de Desenvolvimento Científico e Tecnológico) na modalidade Bolsa de Produtividade em Pesquisa.

${ }^{2}$ Doutora em Educação pela Universidade de São Paulo, Brasil. Professora do Programa de Pós-Graduação em Educação da Universidade de Sorocaba (UNISO), Sorocaba, São Paulo, Brasil. Pesquisadora do Conselho Nacional de Desenvolvimento Científico e Tecnológico (CNPq). 


\begin{abstract}
This article holds a rereading of some works published in the first half of the twentieth century, dedicated and addressed mainly to young Brazilian girls, in an explicit intent to guide their attitudes and standards of conduct in a society that is progressive and enlightened wanted. In these works are highlighted the various female qualities necessary for the care of the home and maternal function, the education needed to meet this goal, as well as some positions as to their inclusion in the public space. Advice, guidance, warnings mix up, all composed to shape an imagery that defined the women identity turned to domesticity and by consequence to the subordinate role that was desired for women in the social hierarchy of the period. The grouping of those works was made by the chronologic criterion because they are sparse and difficult to access.
\end{abstract}

Keywords: female education; magazines; image; gender; identity.

\title{
Introdução
}

O século $\mathrm{XX}$, nas suas décadas iniciais, definiu uma imagem feminina que se espelhava nas formulações do Positivismo e Higienismo do século XIX. De acordo com essa imagética, às mulheres eram atribuídas diversas qualificações. Eram as principais responsáveis pela preservação da família e da moral cristã, possuidoras de atributos de pureza, bondade e submissão e exaltadas como generosas e meigas, em cujas mãos repousavam o futuro da Pátria e da família. No discurso sobre a pureza feminina e qualidades morais das mulheres havia um forte sentido edificado sobre um discurso ambíguo que ora as elevava como preservadoras da raça, ora condenava qualquer ideia de sexualidade, necessária para essa mesma reprodução da espécie. Deveriam aproximar-se do modelo arquetípico reverenciado pela Igreja Católica, a mulher-mãe-virgem isenta dos pecados da conjunção carnal. Esse modelo referendava e preservava os estereótipos da feminilidade e excluía as mulheres dos espaços de protagonismo social ao valorizar apenas seu papel na interioridade dos lares e no desempenho da maternidade.

O lar era o altar sagrado no qual estavam depositadas sua esperança e felicidade. O casamento e a maternidade deveriam ser o ápice de seus melhores e maiores sonhos de realização pessoal. Por esse motivo, eram as indicadas para serem as primeiras educadoras da infância, em cujo fundamento se estruturavam o alicerce da família e o futuro da Pátria. 
A sociedade da época venerava e incensava um comportamento tipificado e de acordo com suas necessidades. Enquanto referendava a ocupação do espaço público pelos homens, mantinha as mulheres nos limites da domesticidade, a elas reservando o cuidado com os filhos que deveriam ser depositários dos seus mais elevados ensinamentos. Se, porventura, houvesse alguma ideia de trabalho por parte das mulheres, este somente seria lícito se significasse cuidar de alguém, doar-se com nobreza, resignação e servir com submissão. Dentro de tais perspectivas, não estava prevista a concorrência com os homens em termos profissionais e intelectuais, o que ultrapassaria os limites de segurança social.

As ideias que orientavam o pensamento das elites intelectuais e se disseminavam entre a população reforçavam essa destinação considerada natural e manifesta nas mulheres, ressaltando seu valor na educação dos filhos e ancorando nesse destino suas necessidades educativas. Eram elas as guardiãs da virtude e para o desempenho de seu papel social deveriam ser educadas dentro dos patamares almejados pelas esferas sociais do período.

As redes de significações que se formavam implicavam numa configuração de valores entre os sexos, em que as práticas, os símbolos, as regras de conduta se estruturavam sob as relações de poder. Interpretava-se a realidade da vida feminina a partir da experiência masculina e dos paradigmas socialmente construídos nas relações de gênero. A alteridade era assentada sobre uma escala axiológica perante a qual as mulheres deveriam se submeter para não incorrerem em desvios que as deixariam proscritas perante a sociedade. Havia, portanto, um padrão de comportamento que também era histórico. Sua regularidade e constância provinham desde os tempos coloniais, legítimos herdeiros de uma Metrópole que também mantinha essa perenidade de hábitos e costumes, reforçados insistentemente pela Igreja católica.

\section{Fragmentos escritos da História: as revistas educacionais e a imagem feminina}

As épocas possuem diversas tonalidades que por vezes ficam diluídas nas análises macroestruturais. Os fatos cotidianos vivenciados por sujeitos únicos, embora inseridos na coletividade e nela promovendo mudanças, viabilizam captar seus códigos verbais e a expressão das suas mentalidades e como estas se construíram. Nisso se insere a obra escrita para e por mulheres, embora estas sejam raras, o que permite fazer emergir atores até então encobertos na vastidão da grande obra histórica. Pinçar retalhos de tempo entrevistos pelas 
frestas do cotidiano pode fornecer o detalhe que faltava, pois: "não é ambição da história fazer reviver, mas recompor, reconstituir, isto é, compor, constituir um encadeamento retrospectivo?" (RICOEUR, 1968, p. 26).

Para Ricoeur (1968), as narrativas prendem-se a um esquema que permite articular circunstâncias, intenções, motivos, derrota e felicidade, entre outros, onde cada coisa encontra um lugar apropriado. Portanto, a cultura é também constituída pelas várias maneiras de contar, pelas paisagens históricas que são desenhadas ao longo do processo investigativo pelo historiador.

Ao compor o discurso de uma época, qualquer narrativa pode revelar a voz dos atores sociais em seu cotidiano ao qual emprestou significação pela via do discurso escrito. Esse discurso, diferentemente do discurso oral, apresenta características de perenidade ao se fixar pela palavra impressa. Se o que realmente aconteceu perdeu-se para sempre, o historiador sente-se herdeiro de uma dívida. Sua tarefa é reconstituir o ausente. E é por isso que a história difere da ficção (RICOEUR, 1990, p. 158).

Na primeira metade do século XX, revistas e livros publicados em Portugal chegavam ao Brasil, nação ainda carente de um corpus literário significativo. Ao serem veiculados, influenciavam a construção do imaginário social na ex-colônia, independente, porém ainda aspirando definir um perfil sociocultural de acordo com sua realidade. Nessa realidade se enquadrava um determinado padrão comportamental que deveria regulamentar a vida das mulheres, o que era veiculado em algumas publicações.

Foram várias as revistas publicadas nesse período e este estudo utilizou-se de duas para exemplificar o teor das ideias que eram veiculadas referentes à área educacional: a revista Formação e O Estudante, dos anos de 1940.

A revista Formação (1941) publicou dois artigos sobre a mulher no serviço público e se posicionou contrária à invasão feminina nesse setor. O autor do primeiro artigo, publicado em janeiro, Artur Negreiro Falcão, considerava-se um convicto e pugnaz defensor do direito de voto à mulher. Afirmou que defendera arduamente seus princípios durante a Constituinte Brasileira de 1933-1934, como também sempre defendeu a atribuição às mulheres dos títulos e capacidades para o exercício social, político e científico de funções, todas erroneamente tidas como privilégio masculino. Porém, assegurava que a concorrência das mulheres contra os homens estava sendo desmedida e instava para que se a regulamentasse, pois o contrário possibilitaria a perda do equilíbrio social desejado.

Essa regulamentação deveria ser urgente, indispensável e inadiável, pois a amplitude ilimitada da atividade feminina ia, a olhos vistos, preparando a crise masculina. Na regulamentação da atividade feminina deveria ser reservada às mulheres apenas a atuação no ensino primário e pré-primário, onde estas se destacariam e onde se lhes descortinariam os mais belos horizontes. O papel de 
educadoras da infância era o mais elevado que as mulheres poderiam aspirar nesse novo país, um lugar importante representado pela culminante missão de ensinar. Enquanto, porém, se não alcançava a era de tão ansiosos ideais de política nacional, a Sociedade deveria cuidar, olhando o amanhã, de opor óbices por uma regulamentação racional aos surtos invasores das mulheres nas regiões burocráticas. Caso contrário o futuro da Pátria estaria seriamente ameaçado ${ }^{3}$.

As repercussões ao artigo parecem ter sido grandes e os bacharelandos da Faculdade de Direito de Niterói, que se afirmavam atentos aos problemas sociais, enviaram posteriormente à revista cópia de um abaixo assinado dirigido a Getúlio Vargas, com o nome $A$ mulher e o serviço público. No texto apelavam por providências ao Presidente, dado que, com a concorrência da mulher nas atribuições do homem, o futuro da Pátria estaria ameaçado, conforme brilhantemente defendera Artur Negreiro Falcão. Não queriam, com essa atitude, combater a mulher, pois seu grande desejo era:

[...] defendê-la e ampará-la; queremos que ela torne ao trono sagrado do lar onde os nossos antepassados a colocaram; queremos para ela a posição de respeito e veneração de que gozaram e ainda gozam nossas mães; queremos que ela volte a ser esposa de seu marido e mãe, no sentido lato, de seus filhos (Formação, 1941, p. 61).

A intenção de que as mulheres permanecessem nos lares possuía como principal argumento a certeza da desagregação da família, se estas continuassem exercendo o trabalho fora do espaço doméstico. Os filhos ficariam abandonados em mãos de serviçais ignorantes, a quem pouco importava a formação do caráter infantil. As únicas pessoas capazes de educarem os filhos à perfeição eram as mães. Para que estas fossem boas nas suas funções era necessário que não tivessem conhecimentos profundos das imperfeições dos homens e muito principalmente da sua vida profana e desregrada. Só assim poderiam com amor e confiança transmitir um pouco dos sentimentos dos seus corações puros e santos, indenes das imperfeições do mundo, para o coraçãozinho do filho. Além de desalojar as mulheres do recesso sagrado do lar, o trabalho feminino apresentava outro aspecto negativo: o de impedir novos casamentos. Pois, a

${ }^{3} \mathrm{O}$ artigo em questão foi primeiramente publicado no Jornal do Comércio, na Bahia, e posteriormente enviado para a revista Formação. Localizou-se alguns exemplares desta revista na Widener Library, Universidade de Harvard, Estados Unidos. Não se tem notícias se existem mais alguns exemplares no Brasil. 
cada mulher que ocupava um emprego, este deixava de ser atribuido para o homem, o qual por tal motivo não se casava.

Asseveravam ainda que a independência econômica feminina dava às mulheres uma situação de liberdade que as poderia iludir e acovardar perante os encargos do matrimônio e as faria querer limitar, senão eliminar, o número de filhos. Além disso, a mulher solteira poderia sentir-se feliz com a liberdade e a autonomia financeira conseguida por uma profissão e por isso rejeitaria o casamento. O mesmo não se dava com os homens que assim que resolviam sua situação econômica, sonhavam em casar-se. Afirmavam ainda que a limitação do número de filhos não se constituía em objeto das cogitações masculinas, partindo sempre da mulher essa exigência. Isso representava um risco social para o país que precisava de homens fortes para o seu desenvolvimento. Sendo assim, não se deveria permitir que as mulheres ocupassem cargos públicos, ocasionando transtornos ao segmento masculino: "a mulher, pela alta missão que lhe compete na sociedade, deve merecer do homem e, sobretudo do Estado, todas as atenções e cuidados que a dignifiquem e lhe proporcionem, tanto quanto possível, um ambiente feliz como filha, noiva, esposa e mãe" (Formação, 1941, p. 63).

Fica claro nas afirmativas acima que as relações de gênero fundamentavam-se numa relação de poder que ultrapassava apenas o contato estrito entre os sexos do ponto de vista biológico ou apenas emocional. Na realidade, o preconceito e a discriminação do sexo feminino revelavam espaços sociais históricos nos quais a alteridade limitava-se por uma imagética feminina impregnada de deveres quanto ao sexo masculino, instaurando paradoxos que carregavam atrás de si os vários impactos sociais do gênero. Não havia uma ideia de uma ação positiva que celebrasse a igualdade entre os sexos, mas sim uma discriminação explícita, embora disfarçada sob um pretenso e relevante papel social a ser desempenhado pelas mulheres.

Os bacharelandos, na moção enviada ao presidente, procederam também a uma análise sobre o casamento do ponto de vista biológico, descrevendo o matrimônio como um encontro sexual entre macho e fêmea do qual resultava a conservação da espécie. Do ponto de vista social humano, o casamento era a regulamentação das relações sexuais entre os homens e as mulheres, tendo em vista o interesse e o bem-estar da mulher e dos filhos. Nos tempos que corriam, um mal denominado feminismo estava corrompendo essa instituição:

[...] o feminismo, nascido na imaginação de algumas que se intitulam 'leaders', veio proclamar em prejuízo da própria mulher e, maior ainda da família que é a célula da sociedade, o absurdo da liberdade, da igualdade e da equiparação dos direitos da mulher aos dos homens. [...] os deveres 
e direitos da mulher é que pela sua própria natureza são maiores, e muito mais, do que os do homem e não está no alcance deste subverter o que Deus determinou (Formação, 1941, p. 64).

Para evitar a ruína da civilização e dos homens, as mulheres deveriam permanecer no lugar que lhes competia e, para isso, os bacharelandos haviam elaborado ao Presidente da República a presente petição e, corroborando sua tese, apontavam vários itens com os resultados negativos da concorrência da mulher nas atribuições dos homens:

1- O retardamento do casamento, quando ele se der;

2- Diminuição, que será sempre crescente, do número de casamentos;

3- Sacrifício irreparável na educação dos filhos, com dano para a família e para a sociedade;

4- Crise que será, também, sempre crescente, no trabalho dos moços, donde a crise do casamento;

5- Redução da natalidade, não só pela crise do casamento como também pela conveniência e comodismo das mulheres casadas e funcionárias;

6- Fonte de adultério e, por isso mesmo, do desquite;

7- Em certos casos trará choques com o Direito, passando o marido, que é cabeça do casal em casa, a subalterno da mulher na repartição;

8- Escola para a desespiritualização da própria mulher, que sendo mais fraca e mais dúctil do que o homem cairá, forçosamente, no materialismo; 9- Fonte de humilhação para o homem, que se sentirá moralmente diminuído com os ordenados maiores das mulheres, estabelecendo uma separação entre entes que a natureza, nas suas leis sábias, procura aproximar; 10- O esfacelamento da família pela falta de assistência da mulher nos seus deveres do lar (Formação, 1941, p. 65).

No final, alertavam ao Presidente da República: "é o quadro que nos espera, se não houver uma reação que corrija essa anomalia social que nos ameaça e cujo remédio se acha na sábia e prudente orientação de V. Excia" (Formação, 1941, p. 66). Conforme aparece transcrito na revista, a petição encaminhada a Getúlio Vargas foi enviada ao Departamento Administrativo do Serviço Público (D.A.S.P.) (identificado como um departamento e pela sigla), que, por sua vez, emitiu parecer discordando das questões levantadas pelos bacharelandos enumerando vinte e três argumentos contrários à sua aceitação pelo chefe da Nação. No número 11 da lista dos contra-argumentos observavam: 
[...] quando em meio ao delírio destruidor da Grande Guerra ficaram entregues à mulher, com as defesas das cidades, os cuidados dos serviços públicos e os mais árduos trabalhos em que muitas se revelaram mais exímias que os homens, rotas ficariam igualmente as últimas barreiras dos preconceitos sociais quanto à nova milícia, enquanto os novos direitos lhes chegavam como uma conquista da dedicação e da coragem que já ninguém possuía razão para contestar (Formação, 1941, p. 68-70).

No parecer do departamento ainda se ressaltou que ao conquistarem os cargos públicos, as mulheres se submeteram a mais rigorosa seleção. Isso significava de fato que os homens não eram insubstituíveis e demonstrava que aqueles que condenavam sua presença nos serviços públicos o faziam mais por motivos de ordem ético-social do que real e efetivo interesse na Administração da Nação. Por fim, parecem ter dado o golpe de misericórdia nas pretensões dos bacharelandos:

Se a causa dos homens está em jogo e com ela a do nosso próprio lar e de nossa sociedade, lar e sociedade que se salvarão do desastre, quando as mulheres voltarem à casa, deixando a função pública, se essa causa está em jogo, cumpre-lhes ganhá-la, vencendo, pela inteligência e pelo esforço, pela capacidade e pelo direito, as usurpadoras que os prejudicam numa ampla competição mista (Formação, 1941, p. 70).

O departamento considerava ainda que forçar a intervenção do Poder Público, em nome de uma moral que não fora por ele criada, mas ao contrário, permitira, na plenitude do direito a todos assegurado, a possibilidade de juridicamente reformar ou substituir uma prerrogativa já concedida, era fazer publicamente a confissão da própria incapacidade, terminando na apologia do que se pretende condenar.

Logo após a publicação do parecer do departamento, a revista Formação apresentou uma transcrição do artigo do bacharelando Ivan Luz, um dos autores da moção, que havia saído na Gazeta de Notícias, no qual este contestava a resposta do D.A.S.P. Nessa contestação, o autor não avançou significativamente no assunto, tornando-se repetitivo, sem apresentar novos argumentos que reforçassem sua ideia inicial. A impressão que se tem é que essa contestação aparece mais como uma forma de dar a última palavra, numa causa já perdida, e para tentar salvaguardar o brio masculino dos bacharelandos. Esse último 
artigo apareceu na revista no mesmo número, logo após o parecer emitido pelo D.A.S.P. Com isso, parece ter-se encerrado a polêmica.

Esse episódio é bastante ilustrativo de uma sociedade e de um período histórico (do qual ainda somos herdeiros) que desconsiderava a mediação feminina no espaço público, sendo que a mediação masculina possuía características revestidas de validez universal. Como, pois, promover a igualdade entre os sexos? No entanto, como em toda relação social, a dialética se impõe dado que, no caso em questão, o poder público fez essa mediação e defendeu a inserção feminina nos espaços públicos, o que leva a concluir que a heterogeneidade de práticas e pensamento sempre se configura como uma marca na sociedade de qualquer época.

No século XX, nas suas décadas iniciais, havia um forte apelo para a atuação feminina no magistério primário público, por conta dos poderes oficiais defenderem essa participação tendo em vista a necessidade crucial de se expandir esse nível de ensino. Nessa defesa, se utilizavam várias simbologias, dentre elas, a vocação, a missão e a maternidade, qualidades que as mulheres eram possuidoras.

Ainda nos anos 1940, a revista $O$ Estudante, publicada em São Paulo, apresentava várias crônicas escritas por uma colaboradora denominada Liloca Amaral, em que esta discutia questões relativas aos direitos das mulheres nos anos que corriam. Nas crônicas tratou de assuntos variados, como o mal causado pela futilidade feminina, alguns péssimos hábitos de mulheres de elite e a mulher nos velhos tempos. Porém, também abordou questões como educação e instrução para o sexo feminino e sua inserção no campo profissional, principalmente num período em que os espaços ocupados pelos homens estavam vazios, com a população masculina envolvida com a guerra:

O preconceito da mulher moderna que trabalha e exerce profissões liberais, está infelizmente bastante arraigado na sociedade [...]. Com a tremenda destruição que assola o mundo, a mulher fatalmente substituirá os homens que ora se perdem nos campos de batalha. De modo que, por força das circunstâncias, ela terá de sair da meia escravidão em que tem vivido até hoje, para iniciar uma fase nova sobre a face da Terra $(O$ Estudante, 1943, p. 24).

Apesar dessas constatações, concluiu que as mulheres, nos tempos que corriam, eram todas escravas e heroínas, por terem de fazer prodígios para manter o lar e cuidar dos filhos. Concordava que cabia à mulher a formação da 
alma e do caráter dos filhos. Para isso, em pleno século XX, mais do que nunca, precisava esta de instrução. Argumentou ainda que a independência trazia benefícios inegáveis para as mulheres do ponto de vista daquelas que escreviam ao jornal, o que não era compartilhado pelos homens. Estes preferiam as mulheres mantidas na ignorância e na submissão por temerem sua inserção profissional e sua independência.

A cronista tinha razão em suas afirmativas, pois os homens mostravam em relação à independência feminina uma atitude de descrédito e antagonismo, como transparece no artigo de um colaborador, que escreveu ao jornal lamentando o que ele denominava a pseudo-independência feminina, que deslocara a mulher do seu verdadeiro papel de mãe e de esposa:

É bem verdade que a educação moderna veio contribuir para a evolução da mulher em muitos sentidos. Hoje, ela já não teme o futuro. Enfrenta-o serena, capaz, na certeza de poder se defender com seu trabalho, com a sua atividade, com sua instrução. Mas, se ganhou em preparo, em atividade, perdeu pelo coração. A mulher de hoje não tem a meiguice, o carinho, o desvelo da mulher de ontem. Ontem ela era toda aflição, toda candura, fazia de seu lar um poema de doces canções; hoje, é dinâmica, viva, sem os encantos próprios de seu sexo [...] Enquanto a mulher não se compenetrar do seu verdadeiro papel de mãe educadora, preparando gerações futuras, os cataclismos que assolam o mundo, tudo devastando, tudo destruindo, continuarão em sua obra demolidora, como um anátema à falsa independência que tirou à mulher o seu símbolo de amor e ternura! ${ }^{4}$

Embora não possua características explícitas de misoginia, a afirmativa revela uma imagem romântica do sexo feminino, imagem essa voltada para um papel de recolhimento e submissão, onde não existia uma mediação com o mundo, mas sim resultante do que se esperava de sua atuação. $\mathrm{O}$ corpo feminino é ritualizado e confinado a espaços próprios. Não existe por si só, é antes um apêndice de cujas derivações se intentava construir uma sociedade modelar. Havia, pois, a ilusão magnificada de modelar, modificar, refrear e construir corpos femininos obedientes e identificados com uma imagem legada pelo passado, imagem nem sempre fruto da realidade, mas sim edificada sobre projeções simbólicas. Em contrapartida, o sexo masculino se despoja das ilusões de culminância moral, possui direitos indiscutíveis amparados apenas na

${ }^{4}$ Do artigo A Mulher, o Lar e a Sociedade, de Itamar Paraguassú. O Estudante, n. 10, s/p, jan./fev. 1943. 
masculinidade, numa relação de gênero de possuidores e possuídas, atitude que a sociedade não só tolera como, muitas vezes, aplaude.

As revistas apresentam alguns vestígios da mentalidade de uma época. Nesta se pode destacar que mesmo com o século XX avançando no rumo do progresso, das comunicações, do desenvolvimento, as mentalidades ainda permaneciam atreladas ao um modelo normativo de mulheres destinadas ao trabalho no lar e na reprodução da raça. Porém, de que mulheres se falavam nesse período? Certamente não das mulheres do povo, mergulhadas nas necessidades básicas de sobrevivência e para quem o trabalho sempre representou uma dura realidade. Não das escravas e das prostitutas, das operárias e camponesas. Falava-se das mulheres de certa projeção social, as destinadas ao casamento e à maternidade, embora mesmo as outras, na duplicidade de valores da relação amorosa, também estivessem sob o jugo e julgamento da dominação masculina e da sociedade.

As revistas, livros, jornais, novelas, manuais de civilidade, orientações médicas, artigos de etiqueta, moda e criação dos filhos voltavam-se para parcelas da sociedade possuidora de poder aquisitivo e que dominavam o cenário nacional da época. Para essas mulheres de elite, as esposas, as mães, as jovens aspirantes ao matrimônio, o pensamento ilustrado, principalmente dos médicos higienistas e eugenistas, buscou encontrar aliadas para fortalecer seus princípios e dar sustentação a uma ideia de sociedade pautada nos valores da família e na pureza da raça.

\section{Os manuais de civilidade ordenando o comportamento feminino}

Nas primeiras décadas do século XX o Brasil se envolveu em acirradas discussões sobre a grandeza da raça e a importância de se edificar um povo $100 \%$ brasileiro e livre das impurezas causadas pela miscigenação racial. Nessa cruzada eugênica se envolveram intelectuais, juristas, professores, médicos, políticos e muitos outros formadores de opinião que se consideravam os baluartes para a defesa da raça brasileira. Havia que se ensinar à população hábitos salutares e modos de vida saudáveis. Dentre estes, a importância das mulheres saberem escolher parceiros conjugais para que a Nação fosse agraciada com filhos saudáveis, livres da degeneração racial resultante da consanguinidade, das moléstias hereditárias e da mestiçagem. Dentre esses atributos para o sucesso dos casamentos, sua perenidade e descendência, ainda havia que se atentar para a situação social equivalente, assim como o nível de instrução de ambos os cônjuges. 
Os anos de 1930 e 1940 também foram prolíficos quanto aos discursos que apontavam para os males advindos do contágio entre raças diferentes. Qualquer tentativa de proximidade com negros, índios e mulatos não era bem recebida, sendo inominável que houvesse sequer o esboço de um movimento nesse sentido, pois a degradação moral e degeneração racial que esse cruzamento desencadearia contaminaria a pureza da raça:

As trilhas ideológicas perfiladas pelos eugenistas, como as teorias de Galton, de Gobineau, de Gustave Le Bom, de Renan e de Taine, entre outros; a fundação da Sociedade Eugênica de São Paulo, à qual se filiaram personalidades até então insuspeitas, como Fernando de Azevedo, as conexões entre lideranças empresariais, políticas e médicas em torno dos ideais eugênicos, que propunham estreita associação entre educação moral, higiene e hereditariedade, manifesta em propostas tais como regulamentação dos casamentos, da imigração, da prostituição e em maior controle psiquiátrico da loucura (ADORNO, Prefácio, apud MARQUES, 1994, p. 15).

A corrente eugênica considerava comprovada cientificamente que a mistura de vários sangues ou raças degeneraria os povos, dentre os quais, o arianismo era o dominante. Para eles a raça humana estava dividida em povos superiores e inferiores. Os povos inferiores eram incivilizáveis e impossibilitados de progredir. Portanto, qualquer contágio racial teria como decorrência, além dos aspectos biológicos negativos, o subdesenvolvimento econômico e a ausência de civilização. No entanto, nem sempre essas teorias eram típicas das questões raciais, pois a população pobre também se enquadrava nesse esquema de periculosidade, independentemente da raça.

$\mathrm{Na}$ época a doença era o inimigo comum e espalhava suas garras predatórias no amontoamento urbano fétido das primeiras décadas do século XX. Os médicos e autoridades impunham, como parte das políticas de educação e saúde, a profilaxia e a higienização dos costumes. Deploravam as práticas maléficas ao bem-estar e ao desenvolvimento. A falta de instrução, aliada à pobreza, permitia também a ausência de higiene das mães e das crianças, o que era causa de mortalidade e gastos governamentais. Havia, pois, que motivar a profilaxia e se alinhar com o saneamento dos corpos e das famílias, protegendo a maternidade e a infância. E a maneira mais eficaz seria impor normas de conduta na sociedade conjugal, criando uma atmosfera propícia à elitização e branqueamento dos costumes. 
As mulheres, pelo potencial admitido de serem as futuras mães, deveriam ser doutrinadas de forma a aspirarem a casamentos que não incidissem nas práticas proibidas. Nas relações de alteridade se impunha um modelo de conduta visando à uniformidade de comportamentos sociais, conjugais e amorosos. Justificava-se essa prática pela crença firmemente arraigada de que assim se fortalecia a Nação e se consolidava o ideal republicano de colocar o País entre as grandes potências mundiais. Isso começava pela formação de famílias eugênicas, bem educadas e de preferência brancas.

\section{Como escolher um bom marido: libelo dirigido às gentis patrícias}

Baseado em conferências proferidas pelo médico Renato Kehl, Presidente da Comissão Central Brasileira de Eugenia, com prefácio assinado por uma mulher que se designava apenas como Eunice e datado de 10/03/1923, com segunda edição de 1935, este pequeno livro foi publicado pela Ariel Editora Ltda, do Rio de Janeiro. Dedicado às "gentis patrícias" seu conteúdo foi tema na Conferência pelo Progresso Feminino realizado em 1922. A segunda parte denominada "O médico e o culto da raça" foi apresentada como conferência no Congresso Nacional dos Práticos, ambos no Rio de Janeiro, em comemoração ao Centenário da Independência do Brasil (1822-1922), conforme identificado na folha de rosto. Do libreto ainda constam os capítulos As Evas do século $X X$, Exame e seleção conjugal, Conselhos para os candidatos ao casamento e Nota Final.

Renato Kehl (1935), autor de dezenas de livros voltados para a temática eugênica e valores físicos e morais para a sociedade, considerado um dos grandes propagadores dos princípios veiculados pela Eugenia, assegurava:

Em se tratando de proteger a espécie contra a degeneração, o que equivale a propugnar pela felicidade dos nossos semelhantes, indicando-lhes os meios de evitar os males, a miséria, as dores, - sinto-me com coragem para perlustrar todos os assuntos, mesmo aqueles ligados à educação sexual, difíceis de serem encarados num meio como o nosso, ainda pouco maduro sob esse ponto de vista. Com estas premissas, a título de explicação, espero merecer o beneplácito das minhas ilustradas leitoras - e entro no tema oportuno e digno de atenção das minhas jovens patrícias, às quais cabe o sagrado dever de zelar pela higidez somato-psíquica dos brasileiros de amanhã (KEHL, 1935, p. 16). 
De acordo com Kehl (1935), para as jovens patricias, nada seria mais natural do que o desejo de unir-se em matrimônio, um passo sério na vida de cada um, pois:

[...] dele depende a felicidade nossa e de nossos filhos, da nossa Pátria e da Humanidade, em suma [...]. Os que se casam devem, pois, ter em mente o patrimônio vital que vão legar aos descendentes, aos quais estará reservada um futuro risonho ou um porvir tenebroso (KEHL, 1935, p. 18).

A maternidade é exaltada como o destino de todas as mulheres, dando assim continuidade aos mandamentos da Igreja Católica quando lhes manda espelharem-se no arquétipo da Virgem: "a função mais nobre da mulher, todos sabemos e proclamamos, é a maternidade; é a função da qual depende a existência da espécie [...] Não depende delas, em grande parte, a raça, o valor da espécie?" (KEHL, 1935, p. 19). Portanto, sem os devidos cuidados na escolha do cônjuge todos sofrerão, pois, afirma, conhecia os desgraçados frutos nascidos desses enlaces infelizes. Apesar disso, já que não existia uma lei eficaz para prevenir essas ligações, continuam a se casar os portadores dos mais diversos males. Por esse motivo e para se contrapor a essa ignorância,

[...] precisamos opor a educação das moças, futuras mães, que devem ser instruídas naquilo que diz respeito às suas funções de mulher, no conhecimento do abismo que se abre aos seus pés com um mau casamento. Às mulheres, mais que aos homens, cabe o papel de defensoras das gerações futuras, prevenindo-se contra os maus casamentos, portanto, contra as más proles. O dever maternal, eugenicamente compreendido, inicia-se com a escolha do marido. Mas, como encontrar um bom marido? (KEHL, 1935, p. 22).

Para o embelezamento e saúde da raça, Kehl (1935) insistia no princípio de que os matrimônios de indivíduos superiores, no sentido eugênico, devem ser mais fecundos que entre os individuos inferiores. Tal fato possibilitaria o progresso da Nação. O contrário causaria sua decadência. Assim, as gerações atuais eram as responsáveis pelo futuro da raça, cuidando para que nasçam filhos fortes, vigorosos e belos, de acordo com o que pregava a Eugenia. Para isso era crucial o concurso feminino, dado que as mulheres sempre preferiam os homens 
mais fortes, mais corajosos, mais audaciosos e mais belos de forma a recair sua escolha para os mais prendados. Assim, a "tendência atual é civilizar o amor, orientando-o para o benefício dos que se casam e da espécie" (KEHL, 1935, p. 58). As mulheres eram, dessa maneira, as melhoras educadoras sanitárias, as melhores defensoras da raça e da Pátria:

Demonstram as nossas patrícias especial pendor pelas questões de higiene e de eugenia. Eis, porque, sou mais propenso a falar-lhes do que aos próprios homens, que, de um modo geral, preocupam-se mais com as questões práticas e imediatas, quando não vivem desatentos aos problemas sérios e à cata de sensações novas, num dispersivo e inglório esforço para satisfazer os sentidos ou para passar o tempo (KEHL, 1935, p. 67).

Kehl (1935) deixou também evidente as diferenças entre meninos e meninas desde a mais tenra idade, ainda nos bancos escolares. Nas classes femininas reinava o asseio, a ordem, a disciplina, a atenção, a vontade de aprender, sempre em harmonia com seus belos vestidinhos. Porém, nas classes masculinas, quando não havia enérgica intervenção do professor, imperava o desalinho, a desordem, a desatenção, a indisciplina, a animosidade e a rixa. Portanto, exortava:

A vós, minhas patrícias está reservado o principal papel junto dos cruzados da higiene e da educação na benemérita obra da salvação nacional. Não vos deveis esquecer de que cuidando de vossos filhos, cuidas das gerações vindouras com as quais se manterá através dos séculos a soberania do Brasil (KEHL, 1935, p. 68).

No capítulo Exame e Seleção Conjugal o autor elenca várias regras para o sucesso e o sentido do casamento, cada uma devidamente justificada:

Regra 1. Escolha sempre um par da mesma condição social.

Regra 2. Tenha sempre em vista a ascendência familiar do par que virá a escolher.

Regra 3. Evite casar-se com pessoa de raça diversa.

Regra 4. Escolha um par em perfeito gozo de saúde física, psíquica e mental. 
Regra 5. Procure um esposo de educação e instrução equivalentes à sua. Regra 6. Dê preferência a um par de situação financeira idêntica ou aproximada.

Regra 7. Verifique antes de casar-se se pode ser verdadeira para com seu esposo e vice-versa.

Regra 8. Não se engane com as belas aparências nem com as belas palavras.

Regra 9. Examine antes de comprometer-se num noivado, se o seu candidato encara a vida com seriedade e com a necessária previdência para assegurar um lar tranquilo e feliz.

Regra 10. Escolha um par de idade conveniente.

Regra 11. Evite casamento consanguíneo.

Regra 12. Procure um jovem de afinidade psíquica e mental, de temperamento, gostos e predileções aproximadas, a fim de evitar desentendimentos e malquerenças.

Regra 13. Evite um par de gosto e tendências exclusivas quando estas não afinam pelos seus.

Regra 14. Evite casar-se com um jovem com cuja profissão não se conforma.

Regra 15. Antes de dar o último passo para o compromisso matrimonial, leia todas as regras acima, pondere o que vai fazer e o que poderá acontecer, tendo sempre em mente que, casando-se, não vai viver para si só, mas para a família, para a descendência e para a humanidade (KEHL, 1935, p. 71-81).

Essas orientações mostram como estava arraigado no imaginário social o papel que deveria ser representado pelo sexo feminino e as relações de gênero que se objetivava fortalecer. Na ordem hierárquica de poder era indubitavelmente um sistema de dominação de gênero que viabilizava que vidas femininas estivessem subjugadas a uma imagem e identidade voltadas para o desempenho do papel de servir, não importando com que roupagens de romantismo e amorosidade essa imagética as adornassem. A dura realidade era a ausência de autonomia, a dilapidação de possíveis e viáveis talentos, as oportunidades perdidas.

\section{Finalizando...}

Tradicionalmente, a História se esqueceu das mulheres. Escrita pelos homens, cujos feitos foram ressaltados, suas vidas exaltadas e heroicizadas: 
La historia andocéntrica, escrita solamente por varones, recuperó la experiência masculina. Así, la historia universal nos legó las luchas por el poder, la vida de los soberanos, los conflictos armados, los sistemas económicos, políticos y sociales, silenciando e minimizando todo aquello que suponía invertir la mirada masculina. Em ocasiones, cuando la historia se ha dedicado a recuperar a las mujeres, lo ha hecho también dentro de las nociones patriarcales, analizando como "la complementariedad" ha funcionado desde antanho (LOZANO, 2007, p. 171).

O feminismo permitiu que uma história escrita principalmente por mulheres começasse a se preocupar em lhes dar visibilidade, porém são raras as fontes, são dispersos os documentos que assinalem sua presença no entorno social. Essa história ainda está sendo escrita, graças a esforços, principalmente, das pesquisadoras de gênero, pois ainda são raros os homens dedicados a essa investigação. Estamos na fase de buscar desvendar o passado para iluminar o presente e, quiçá, tornar o futuro mais favorável para as novas gerações. E nesse processo de desvendamento, assume grande importância compor com os retalhos de informações de que dispomos uma história que reconheça que foram os dois sexos que edificaram a sociedade e o mundo no qual vivemos - uma difícil tarefa, reconheçamos!

As fontes utilizadas representam apenas alguns fragmentos e vestígios de uma época, mas permitem apontar algumas pistas para a interpretação histórica que não seja somente a baseada nos fatos oficiais, sabedores hoje que somos, que estes nem sempre são representativos do que realmente ocorreu no passado histórico. Como afirma Chartier (1990, p. 63):

A relação do texto com o real (que pode talvez se definir como aquilo que o próprio texto apresenta como real, construindo-o como um modelo referente situado no seu exterior) constrói-se segundo modelos discursivos e delimitações intelectuais próprios de cada situação de escrita. O que leva, antes de mais, a não tratar as ficções como simples documentos, reflexos realistas de uma realidade histórica, mas a atender à sua especificidade enquanto texto situado relativamente a outros textos e cujas regras de organização, como a elaboração formal, têm em vista produzir mais do que mera descrição. [...] O real assume assim um novo sentido: aquilo que é real, efetivamente, não é (o não é apenas) a realidade visada pelo texto, mas a própria maneira como ele a cria, na historicidade da sua produção e na intencionalidade da sua escrita. 
Para o sexo feminino vivemos um momento de preencher lacunas e reescrever a História, justamente por conta da notória invisibilidade já assinalada. Esse movimento está em fase de ruptura há alguns anos por conta de inúmeros trabalhos que têm procurado interpretar o protagonismo feminino pelos documentos possíveis de serem encontrados, mesmo assumindo muitas vezes a falibilidade desse procedimento. Porém, essa construção tem avançado e permitido olhar um pouco além do que apenas através do legado da cultura e da interpretação das fontes oficiais.

Pode-se, pela análise realizada, considerar que na primeira metade do século $\mathrm{XX}$, as mulheres, mantendo a mentalidade do século anterior, continuavam vistas como seres dotados de atributos de pureza e doçura, responsáveis pela preservação da família e da moral cristã, mães generosas, espíritos de sacrifício, salvadoras da pátria, o que as colocava como responsáveis por toda a beleza e bondade que deveriam impregnar a vida social. Mesmo tendo introduzido um avanço em relação aos séculos anteriores, quando o mistério e as crendices herdadas da Idade Média ainda influíam nessas representações, na realidade, os modelos de domesticidade e o forte apelo à maternidade foram determinantes para a manutenção da subordinação feminina aos padrões sociais e morais masculinos. O discurso da pureza feminina e das suas qualidades morais armava-se de ambiguidades e prestava-se admiravelmente bem para referendar o mito da inferioridade biológica baseado nas diferenças sexuais. Esses princípios referendavam os estereótipos acerca da feminilidade de forma a justificar a exclusão das mulheres dos espaços de protagonismo social.

O pensamento social, assim como a Eugenia, valorizava as mulheres como mães e esposas abnegadas, para quem o lar era o altar no qual depositavam sua esperança de felicidade, a qual se assentava em dois pilares: o casamento e a maternidade. Eram também as primeiras educadoras da infância e os sustentáculos da família e da Pátria. Na imagem assim moldada havia os referenciais básicos representados pela fidelidade, moralidade, recato, submissão, amorosidade e obediência. Não corresponder a essa imagética significava uma absoluta rejeição social.

As diferenças biológicas referendavam uma ideia de sociedade que necessitava da presença feminina e serviam para justificar a ocupação do espaço público pelos homens, segregando-se as mulheres nos limites do privado e reservando a elas o cuidado com os filhos que deveriam ser depositários dos seus ensinamentos morais. As mulheres educadas dentro das aspirações masculinas seriam companhias mais agradáveis para os homens que transitavam regularmente no espaço urbano. O trabalho somente poderia ser lícito se significasse cuidar de alguém, doar-se com nobreza e resignação, e servir com submissão, qualidades inerentes às mulheres. 
A República brasileira que se espelhava no modelo europeu e norte-americano teria possibilitado que a Eugenia fosse a nova religião em contraponto aos dogmas católicos da Colônia e do Império? Certamente, a imagem da raça branca, pura e livre das contaminações das raças inferiores, devia impregnar o imaginário de uma sociedade que se queria progressista e aspirava figurar entre os principais conglomerados urbanos do hemisfério norte. Como aceitar a evidente latinidade se esta levava a ideias de subdesenvolvimento, feiura, cor, pobreza, inferioridade?

Somos, portanto, os legítimos herdeiros de ideologias racistas e sexistas. Não é, pois, de admirar que ainda hoje estejamos nos debatendo com nossa identidade. Assim como não é de se admirar que ainda figuremos como um País de extrema violência contra as mulheres, embora as políticas governamentais e as pesquisas ainda estejam longe de uma verdadeira ação afirmativa quanto ao preconceito e à discriminação, seja de classe, de sexo ou de raça.

\section{REFERÊNCIAS}

ADORNO, Sérgio. Prefácio. In: MARQUES, Vera R. B. A medicalização da raça: médicos, educadores e discurso eugênico. Campinas, SP: Ed. Unicamp, 1994.

CHARTIER, Roger. A História Cultural: entre práticas e representações. Rio de Janeiro: Bertrand Brasil, 1990.

KEHL, Renato. Como escolher um bom marido: regras práticas. 2. ed. Rio de Janeiro: Ariel Editora, 1935.

LOZANO, Fernanda Gil. Historia y Mujer (verbete). In: GAMBA, Susana Beatriz (Coord.). Diccionario de estudios de género y feminismos. Buenos Aires: Biblos, 2007.

MARQUES, Vera, R. B. A medicalização da raça: médicos, educadores e discurso eugênico. Campinas, SP: Ed. Unicamp, 1994.

REVISTA Formação, Revista Brasileira de Educação, Ano IV, n. 30, jan. 1941.

REVISTA $O$ Estudante, São Paulo, n. 10, jan./fev. 1943.

RICOEUR, Paul. Entrevistas do Le Monde: filosofias. São Paulo: Ática, 1990. . História e Verdade. Rio de Janeiro: Forense, 1968.

Texto recebido em 30 de abril de 2011.

Texto aprovado em 30 de novembro de 2012. 